\title{
THE PERMIAN GASTROPODS OF NEW SOUTH WALES
}

\author{
By H. O. Fletcher \\ (Plates 7-21) \\ (Manuscript received 4.9.57)
}

\section{SUMMARY}

The Permian gastropod fauna of New South Wales is revised and 7 new genera and 16 new species are described and figured.

For the purposes of correlation gastropods have proved to be an unsatisfactory group. This is because they appear to be very susceptible to environmental changes and many species develop within a sequence to a marked extent in comparatively narrow limits both horizontally and vertically. Some species, however, form valuable "marker" or "index" fossils for certain horizons of limited extent.

In this paper a correlation of the Permian horizons in New South Wales is made, so far as is possibie, from a study of the gastropod fauna. Special attention is directed towards the uncertain correlations of the "rock unit subdivisions" of the South Coast with those of the Hunter River Valley.

The study of the Permian gastropods has led to certain interesting correlations, but attempts made to correlate the complete sequence of Permian rocks of the South Coast with those of the Hunter River Valley have been impossible.

\section{INTRODUCTION}

Rocks of Permian age cover considerable portions of fairly widely separated areas in New South Wales. A great deal of attention has been directed to these rocks for more than a century because of the economic importance of the coal seams found in the Upper Coal Measures, the Greta Coal Measures and their equivalents.

The type locality of the Permian rocks in New South Wales is in the lower Hunter Valley where a complete and continuous sequence occurs. In this area, as well as over most of the Sydney Basin, the Newcastle Coal Measures pass upwards without angular unconformity into the overlying Narrabeen Group of Lower Triassic age. The basal glacial shales of the Permian rest also without angular unconformity upon the Kuttung Group of the Carboniferous.

The geology of the Permian areas in New South Wales has been thoroughly investigated over the years and the stratigraphy is well known, particularly in the Hunter River Valley. There is still some doubt, however, regarding the exact succession of "rock units" of the Upper Marine Series which are found outcropping on the South Coast from Wollongong to near Durras Waters a few miles north of Bateman's Bay.

The great abundance and variety of well preserved fossils found in both the Maitland (Upper Marine) and Dalwood (Lower Marine) Groups and their equivalents, has attracted the attention of palaeontologists in the past and many important contributions to knowledge have been published. Nevertheless knowledge of the marine fauna is inadequate and surprisingly incomplete.

\section{HISTORICAL REVIEW OF PERMIAN GASTROPODS WITHIN NEW SOUTH WALES}

The first Permian gastropod from New South Wales was recorded in 1838 when James D. Sowerby figured, but did not describe, a medium sized shell as "The Trochus ... . may be called T. oculus". His figures of this specimen were idealised to some extent and photographs provided by the British Museum have proved certain inaccuracies.

The location of this specimen is mentioned by Mitchell (1838) as : "A hill of some height on the right bank, situate some twenty-six miles from the sea-shore, is composed chiefly of a volcanic grit of greenish-grey colour, consisting principally of felspar, and being in some parts slightly calcareous, in other parts highly calcareous when the rock assumes a compact aspect.... This rock contains numerous fossils." This hill in the Hunter River Valley, now known as Harper's Hill, is the type locality for many fossil species. On the same horizon, the Allandale Formation of the Dalwood (Lower Marine) Group, are nearby localities referred to in literature as Allandale, Duguid's Hill, and "Lochinvar", a locality occasionally listed for early material obviously collected at Harper's Hill.

A series of gastropods collected from Harper's Hill, Glendon and Illawarra by P. E. de Strzelecki was described by J. Morris (1845: 285-288). The specimens are housed in the collection of the British Museum. The name Illawarra now refers to a district of considerable extent on the South Coast, but it is almost certain that Strzelecki collected his fossils at Wollongong, about 50 miles south of Sydney. Glendon is a locality in the Hunter River Valley which is referred to by several of the early authors, but there is doubt regarding its actual geographical position. The locality was usually accepted as being on the northern bank of the Hunter River about 9 miles east of Singleton. This must be incorrect as the exposed rocks in that area are unfossiliferous.

*30936-1 